\title{
Rasio Jumlah Neutrofil-Limfosit pada Awal Masuk Rawat sebagai Faktor Risiko Luaran Pneumonia Anak
}

Farah Katleya, MS Anam, Dwi Wastoro Dadiyanto

Bagian/SMF Ilmu Kesehatan Anak Fakultas Kedokteran Universitas Diponegoro/RSUP Dr. Kariadi, Semarang

\begin{abstract}
Latar belakang. Data global menunjukkan pneumonia pada anak usia di bawah 5 tahun (balita) menyebabkan kematian $15,5 \%$. Neutrophil to lymphocyte count ratio (NLCR) atau rasio jumlah neutrofil-limfosit merupakan parameter inflamasi sistemik dan stres untuk pasien kritis. Dari beberapa penelitian didapatkan hubungan antara derajat keadaan klinis dengan peningkatan NLCR

Tujuan. Membuktikan nilai NLCR awal masuk sebagai faktor risiko luaran pasien pneumonia anak yang dirawat di bangsal anak RSUP dr Kariadi

Metode. Penelitian kohort prospektif pada anak pneumonia usia 1 bulan -5 tahun yang dilaksanakan di ruang perawatan anak (bangsal anak, HCU, PICU) RS dr Kariadi, Semarang. Subjek yang memenuhi kriteria inklusi dilakukan pemeriksaan darah rutin, kemudian dilakukan pemantauan klinis pada hari perawatan ke 10. Pada spesimen darah diperiksa darah rutin dan dilakukan perhitungan NLCR. Analisis statistik menggunakan uji chi square dan Mann-Whitney U

Hasil. Didapatkan 40 subjek dengan pneumonia. Rerata NLCR lebih tinggi pada luaran yang buruk dari pada luaran yang baik $(3,42 \pm 4,063)$ vs $(1,73 \pm 1,568)$ tetapi tidak berbeda bermakna $(\mathrm{p}=0,118)$. Titik potong NLCR $\geq 1,335$ meningkatkan risiko luaran perburukan pada pneumonia anak sebesar 1,727 kali

Kesimpulan. Tidak terdapat perbedaan nilai NLCR awal antara luaran perbaikan dan perburukan. Titik potong dari NLCR awal tidak dapat digunakan sebagai indikator prognosis luaran pneumonia anak. Sari Pediatri 2015;17(1):47-51.
\end{abstract}

Kata kunci. rasio jumlah neutrofil-limfosit, pneumonia anak, luaran

\section{Neutrophil to Lymphocyte Count Ratio as a Risk Factor of Outcome in Children Pneumonia}

Farah Katleya, MS Anam, Dwi Wastoro Dadiyanto

Background. Pneumonia causes 15, 5\% mortality among children under five globally. Neutrophils to lymphocytes count ratio (NLCR) is a marker in predicting systemic inflammation and stress for critically ill patients. There is correlation between elevated of NLCR and severity of clinical manifestations.

Objective. To determine level of NLCR at admission as a risk factor of outcome in children with pneumonia at Dr. Kariadi Hospital, Semarang.

Methods. A prospective cohort study in 40 children aged 1 month to 5 years old with pneumonia. Subject that fulfilled the inclusion criteria will have a laboratory test with calculation of the NLCR and 10 days monitoring for the outcome. The good outcome was determined by the clinical improvement at day ten. Chi square and Mann Whitney U test were used for statistic analysis.

Results. The mean of NLCR at admission was higher in poor compared to children with good outcome $(3.142 \pm 4063$ vs $1.73 \pm$ 1568 ), but the difference was not significant $(\mathrm{p}=0.118)$. Area under curve (AUC) of NLCR at admission in this study is 0.658 this value can not be used as an prognostic indicator of outcome. The NLCR $\geq 1.335$ can increased poor outcome of children with pneumonia, for 1.727 times higher, however it is not significant.

Conclusion. There are no differences of NLCR at admission between poor and good outcome. The NLCR ratio at admission can not be used as a predictor of outcome in children with pneumonia. Sari Pediatri 2015;17(1):47-51.

Keyword: neutrophil to lymphocyte count ratio, pediatric pneumonia

Alamat korespondensi: Dr. MS. Anam, MSi. Med, Sp.A. Divisi Respirologi, Bagian/SMF Ilmu Kesehatan Anak Fakultas Kedokteran Universitas Diponegoro/RSUP Dr. Kariadi, Semarang. E-mail: anam@idai.or.id, msanamped2010@gmail.com 
$\mathrm{P}$ neumonia merupakan penyebab kematian utama anak di bawah usia lima tahun di dunia, lebih banyak dibandingkan dengan penyakit lain seperti AIDS, malaria, dan campak. Angka kematian pneumonia di dunia masih tinggi, yaitu dari 9 juta kematian balita setiap tahun dan lebih dari 2 juta meninggal akibat pneumonia atau sama dengan empat orang meninggal setiap menit. ${ }^{1}$

Parameter inflamasi nonspesifik seperti leukosit, jumlah neutrofil absolut (ANC), C-reaktif protein (CRP), dan laju endap darah (LED) menunjukkan derajat reaksi inflamasi pada fase akut dan sering digunakan untuk menunjukkan infeksi bakteri. Hasil pengukuran dari parameter tersebut diharapkan tinggi pada infeksi bakteri dari pada virus. Namun, hasil pemeriksaan kultur darah positif kurang dari 5-10 persen pada anak dengan pneumonia. ${ }^{2,3}$

Jumlah leukosit abnormal merupakan faktor yang berhubungan dengan mortalitas. Jumlah leukosit tinggi merupakan salah satu indikator yang menunjukkan derajat penyakit dan berhubungan dengan mortalitas. ${ }^{2}$ Neutrofil yang terganggu, baik fungsi maupun jumlah, dapat meningkatkan morbiditas dan mortalitas pada anak dan bayi. ${ }^{4}$

Neutrofilia dan limfositopenia merupakan penanda infeksi bakteri. ${ }^{5}$ Zahorec $\mathrm{dkk}^{6}$ telah meneliti rasio jumlah neutrofil-limfosit (NLCR) sebagai parameter terukur yang mudah untuk menunjukkan derajat peradangan dan sepsis pada 90 pasien onkologi. Populasi sel darah putih (limfosit dan neutrofil) memainkan peran penting pada respons inflamasi sistemik terhadap infeksi berat, trauma, dan syok. Respon imun terhadap endotoksemia ditandai dengan peningkatan neutrofil yang bersirkulasi dalam darah dan jumlah limfosit yang rendah. ${ }^{6}$ Menurut Zahorec, terdapat hubungan antara beratnya kondisi klinis dengan jumlah neutrofil yang meningkat dan limfosit yang rendah. ${ }^{6}$

Penelitian ini bertujuan untuk mengetahui apakah rasio jumlah neutrofil-limfosit (NLCR) dapat digunakan sebagai prediktor luaran pasien pneumonia anak.

\section{Metode}

Desain penelitian adalah kohort prospektif yang merupakan pengembangan penelitian surveilance of severe acute respiratory infection (SARI) yang dilaksanakan di delapan rumah sakit di Indonesia. Penelitian dilakukan di Bangsal Bagian Ilmu Kesehatan Anak RSUP dr. Kariadi, Semarang, selama April 2011 sampai dengan Desember 2012.

Subjek penelitian adalah pasien pneumonia anak, berumur 1 bulan sampai 5 tahun yang dirawat selama kurun waktu penelitian dan memenuhi kriteria penelitian. Kriteria inklusi apabila orang tua pasien mengijinkan anaknya diikutsertakan dalam penelitian. Sebaliknya, kriteria eksklusi adalah pasien dengan kelainan sistem imun, seperti HIV/AIDS atau keganasan, menderita kelainan jantung, kistik fibrosis, tuberkulosis paru, dan asma.

Jumlah subjek penelitian dihitung menggunakan rumus besar sampel untuk penelitian kohort prospektif. Nilai kesalahan tipe I ditetapkan $5 \%(\alpha=0,05)$, nilai kesalahan tipe II $20 \%(\beta=0,2)$ dengan power penelitian $80 \%$ maka didapatkan perhitungan besar sampel minimal 40 anak dengan pneumonia.

Faktor risiko pneumonia yang dinilai adalah berat badan lahir rendah, pemberian ASI tidak eksklusif, dan status gizi. Diagnosis pneumonia ditetapkan berdasarkan anamnesis, pemeriksaan fisik, pemeriksaan penunjang hematologi, mikrobiologi, dan X-foto dada.

Pengambilan sampel dengan cara consecutive sampling sampai besar sampel terpenuhi. Pada spesimen darah vena dilakukan pemeriksaan darah perifer, dan hitung jenis di laboratorium Patologi Klinik Universitas Diponegoro/RS. Dr. Kariadi, Semarang. Pemeriksaan darah perifer dan preparat darah tepi menggunakan mesin analisis sel hematologis otomatis, Cell dyne 3700 yang telah dikalibrasi secara rutin. Dilakukan pemantauan selama 10 hari perawatan, untuk menentukan luaran dari pneumonia. Dikatakan luaran perbaikan jika pada hari ke-10 atau kurang terjadi perbaikan gejala klinis. Perburukan klinis, atau meninggal pada hari ke-10 disebut perburukan.

Data yang terkumpul dilakukan perhitungan rasio neutrofil-limfosit dihubungkan dengan luaran pasien. Analisis kurva ROC dilakukan untuk mengetahui apakah rasio jumlah neutrofil-limfosit dapat dipergunakan sebagai prediktor prognosis luaran pneumonia. Didapatkan luas area di bawah kurva $\geq 0,7$ maka rasio jumlah neutrofil-limfosit dapat dipergunakan sebagai prediktor prognosis luaran pneumonia. Selanjutnya, ditentukan nilai cut-off-point rasio neutrofil-limfosit sebagai indikator prognosis luaran pneumonia. Setelah itu, analisis dilakukan untuk menentukan risiko relatif (RR). Uji 
statistik dianggap bermakna apabila nilai $\mathrm{p} \leq 0,05$, rentang interval kepercayaan ditetapkan $95 \%$. Analisis dilakukan dengan program komputer SPSS 15.

\section{Hasil}

Selama periode penelitian didapatkan 40 anak yang dirawat dibangsalanak, HCU dan PICU yang sesuai dengan kriteria penelitian. Karakteristik subjek penelitian tertera pada Tabel 1.

Tidak terdapat perbedaan bermakna antara kelompok yang mengalami perbaikan dengan yang mengalami perburukan dalam hal jenis kelamin, usia, status gizi, berat lahir, jumlah leukosit dan neutrofil, serta usia kehamilan $(p>0,05)$. Sebaliknya, ASI eksklusif menunjukkan perbedaan bermakna dengan nilai $\mathrm{p}<0,05$.

Rasio neutrofil-limfosit pada 40 subjek memiliki rentang 0,28 sampai dengan 14,8 dengan median 1,28 . Sementara luaran pneumonia didapatkan 28 subjek mengalami perbaikan dan 12 subjek mengalami perburukan.
Nilai NLCR berdasarkan luaran tertera pada Tabel 2, menunjukkan median dari NLCR lebih tinggi pada luaran perburukan 1,91 , dengan nilai mínimum 0,3 dan maksimum 14,8. Rasio pada kelompok prognosis buruk lebih tinggi daripada prognosis baik dengan selisih 0,86 $(\mathrm{p}=0,118)$. Didapatkan median rasio jumlah neutrofil terhadap limfosit pada kelompok luaran perburukan lebih tinggi, tetapi tidak bermakna dibandingkan kelompok luaran perbaikan ( $>0,05)$.

Hasil analisis ROC pada Gambar 1 menunjukkan luas area di bawah kurva ROC adalah $0,6-0,7$, yaitu 0,658 . Nilai tersebut menunjukkan bahwa rasio jumlah neutrofil terhadap limfosit kurang memiliki

Tabel.2. Perbandingan rasio neutrofil/limfosit antara subjek dengan luaran buruk dan luaran baik

\begin{tabular}{lcc}
\hline Luaran pneumonia & Median & $\mathrm{p}$ \\
\hline Perbaikan & $1,05(0,28-5,9)$ & $0,118^{*}$ \\
Perburukan & $1,91(0,3-14,8)$ & \\
\hline Total & $1,28(0,28-14,8)$ & \\
\hline
\end{tabular}

*Uji Mann-Whitney; variabel rasio disajikan dalam median (minimummaksimum).

Tabel 1.Karakteristik subjek

\begin{tabular}{lccc}
\hline \multirow{2}{*}{ Karakteristik } & \multicolumn{2}{c}{ Luaran pneumonia } & \multirow{2}{*}{$\mathrm{p}$} \\
\cline { 2 - 3 } Jenis kelamin (\%) & Perbaikan & Perburukan & \\
$\quad$ Laki-laki & $16(57,1)$ & $5(41,7)$ & $0,369^{*}$ \\
$\quad$ Perempuan & $12(42,9)$ & $7(58,3)$ & \\
Umur (bulan, \%) & & & $0,203^{* *}$ \\
$1-3$ & $3(10,7)$ & $4(33,3)$ & $0,156^{*}$ \\
$4-12$ & $17(60,7)$ & $4(33,3)$ & \\
$13-60$ & $8(28,6)$ & $4(33,3)$ & \\
Status gizi (\%) & & & \multirow{2}{*}{$1,000^{*}$} \\
$\quad$ Baik & $24(85,7)$ & $10(83,3)$ & \\
Buruk/kurang & $4(14,3)$ & $2(16,7)$ & \\
ASI eksklusif (\%) & $13(46,4)$ & $1(8,3)$ & $0,030^{*}$ \\
$\quad$ Ya & $15(53,6)$ & $11(91,7)$ & \\
$\quad$ Tidak & & & \\
Berat lahir (\%) & $5(17,9)$ & $5(41,7)$ & $0,133^{*}$ \\
$\quad$ Normal & $23(82,1)$ & $7(58,3)$ & \\
BBLR & & & \\
Usia kehamilan (\%) & $25(89,3)$ & $10(83,3)$ & $0,627^{*}$ \\
$\quad$ Cukup bulan & $3(10,7)$ & $2(16,7)$ & \\
$\quad$ Prematur & $16270,3 \pm 7667,8$ & $15129,1 \pm 9523,4$ & $0,417^{* *}$ \\
Jumlah leukosit & $51,3 \pm 17,2$ & $61 \pm 21,4$ & $0,137^{* * *}$ \\
Jumlah neutrofil (\%) & & & \\
\hline
\end{tabular}

Keterangan: ${ }^{*}$ chi square test,${ }^{* *}$ Mann whitney test ${ }^{* * *}$ Independent $t$ test 


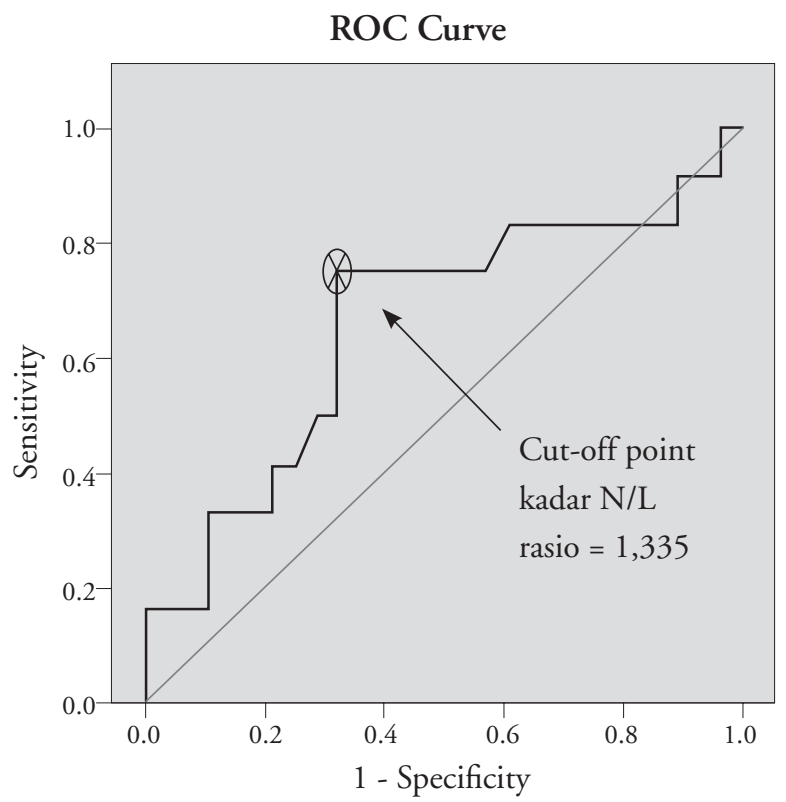

Diagonal segments are produced by ties.

Gambar 1. Penentuan titik potong optimal rasio neutrofil/ limfosit. Titik potong optimal pada $\geq 1,335$ (sensitivitas $75 \%$, spesifisitas $67,9 \%$ )

keakuratan dalam diagnostik untuk dapat digunakan sebagai indikator prognostik luaran pneumonia pada anak $(\mathrm{p}=0,013)$.

Nilai cut-off point untuk NLCR adalah 1,335. Selanjutnya, dilakukan análisis untuk menentukan nilai risiko relatif NLCR $>1,335$ terhadap luaran pneumonia seperti tertera pada Tabel.3

Dari Tabel 3 didapatkan rasio jumlah neutrofillimfosit $>1,335$ memiliki kemungkinan untuk mendapat luaran perburukan 1,727 kali $(\mathrm{p}=0,013)$.

Pada penelitian ini didapatkan variabel ASI eksklusif sebagai variabel yang ikut memengaruhi luaran pneumonia sehingga dilakukan análisis Maentel Haentzel untuk mengontrol faktor perancu. Menurut analisis Maentel Haentzel, nilai RR keseluruhan berada di antara nilai RR masing-masing strata maka variabel ASI merupakan variabel interaksi yang memperkuat hubungan antara pneumonia dengan luarannya.

\section{Pembahasan}

Didapatkan NLCR pada pasien pneumonia yang mengalami perbaikan antara 0,28-5,9 dengan rerata NLCR $(1,73 \pm 1,568)$, sedangkan NLCR pada pasien yang mengalami perburukan antara 0,3-14,8 dengan rata-rata NLCR $(3,42 \pm 4,063)$. Hasil NLCR tersebut berbeda dengan subjek pneumonia dewasa, yaitu $(23,3 \pm 16,8)$ pada dewasa yang meninggal karena pneumonia. ${ }^{8}$ Sementara pada penelitian ini didapatkan NLCR pasien yang mengalami luaran perbaikan dan perburukan tidak menunjukkan perbedaan. Hal ini disebabkan jumlah subjek yang diteliti kurang banyak.

Rasio neutrofil-limfosit tidak dapat digunakan sebagai indikator prognosis luaran pneumonia karena luas area di bawah kurva ROC $<0,7$ adalah 0,658 dengan titik potong optimal pada $\geq 1,335$. Penelitian yang dilakukan oleh De Jager $\mathrm{dkk}^{8}$ pada subjek dewasa didapatkan AUC 0,701, yang merupakan nilai tertinggi dibandingkan dengan penanda infeksi yang lain seperti jumlah neutrofil $(0,681)$, jumlah leukosit $(0,672)$, jumlah limfosit $(0,630)$, dan CRP $(0,565)$. Hasil penelitian tersebut menunjukkan bahwa NLCR dapat digunakan sebagai prediktor mortalitas pada kasus community acquired pneumonia dibandingkan penanda konvensional lainnya. ${ }^{8}$

Air susu ibu eksklusif memberikan kemungkinan luaran pneumonia yang lebih baik dibandingkan pasien yang tidak mendapatkan ASI eksklusif. Pada penelitian meta analisis terhadap tujuh penelitian kohort oleh Bachrach dkk ${ }^{9}$ didapatkan bayi yang tidak mendapatkan ASI eksklusif memiliki risiko 3,6 kali untuk mendapatkan perawatan di rumah

Tabel 3. Rasio jumlah neutrofil-limfosit dan luaran pneumonia

\begin{tabular}{|c|c|c|c|c|c|c|}
\hline \multirow{2}{*}{ NLCR } & \multicolumn{2}{|c|}{ Luaran pneumonia } & \multirow[b]{2}{*}{$\mathrm{p}$} & \multirow{2}{*}{$\mathrm{RR}$} & \multicolumn{2}{|c|}{ IK95\% } \\
\hline & Perbaikan (\%) & Perburukan (\%) & & & Bawah & Atas \\
\hline$<1,335$ & $19(67,9)$ & $3(25)$ & $0,013^{*}$ & 1,727 & 1,057 & 2,822 \\
\hline$>1,335$ & $9(32,1)$ & $9(75)$ & & & & \\
\hline Jumlah & $28(70)$ & $12(30)$ & & & & \\
\hline
\end{tabular}

Keterangan: * chi square test 
sakit karena infeksi saluran pernapasan bagian bawah pada tahun pertama kehidupan (IK95\%, 1,9-7,1). Penelitian Nataprawira $\mathrm{dkk}^{10}$ pada pasien anak dengan pneumonia mendapatkan hasil anak yang tidak mendapatkan ASI eksklusif memiliki waktu perawatan RS lebih lama. Sementara penelitian lainnya, Lamberti $\mathrm{dkk}^{11}$ mendapatkan hasil bahwa kematian karena pneumonia lebih tinggi pada ASI yang tidak eksklusif dibandingkan pada anak yang mendapatkan ASI eksklusif (RR 1,92; IK95\%: 0,79-4,68). Sebaliknya, pemberian ASI tidak eksklusif akan memberikan risiko terjadinya pneumonia pada anak usia 6-23 bulan 1,93 kali lebih besar dari yang mendapatkan ASI eksklusif (RR:1,93; IK95\%:1,39-2,69).

Keterbatasan pada penelitian ini adalah penentuan cut off point, membutuhkan jumlah sampel yang lebih banyak untuk menggambarkan nilai rasio jumlah neutrofil-limfosit yang dapat mewakili populasi. Selain itu, keterbatasan waktu penelitian menyebabkan tidak semua variabel-variabel yang dapat menjadi faktor risiko luaran pneumonia dapat diteliti.

\section{Kesimpulan}

Tidak didapatkan perbedaan dari nilai rasio jumlah neutrofil-limfosit awal masuk rawat pada luaran perbaikan dan perburukan. Cut off point dari rasio jumlah neutrofil-limfosit awal masuk tidak dapat digunakan sebagai indikator prognosis, sehingga rasio jumlah neutrofil-limfosit awal masuk rawat tidak dapat digunakan sebagai indikator prognosis luaran pneumonia anak.

\section{Daftar pustaka}

1. Departemen Kesehatan. Laporan Riset Kesehatan Dasar (Riskesdas). Bidang Biomedis, Jakarta: Badan Litbangkes
RI; 2010.

2. Tiewsoh K, Lodha R, Pandey RM, Broor S, Kalaivani M, Kabra SK. Factors determining the outcome of children hospitalized with severe pneumonia. BMC Pediatrics 2009;9:1-8

3. Korppi M, Heiskanen-Kosma T, Leinonen M. White blood cells, C-reactive protein and erythrocyte sedimentation rate in pneumococcal pneumonia in children. Eur Respir J 1997;10:1125-9

4. Lakshman R, Finn A. Neutrophil disorders and their management. J Clin Pathol 2001;54:7-19

5. Holub M, Beran O, Kasprikova N, Chalupa P. Neutrophil to lymphocyte count ratio as a biomarker of bacterial infections. Cent. Eur. J Med 2012;7:258-61

6. Zahorec R. Ratio of neutrophil to lymphocyte countrapid and simple parameter of systemic inflammation and stress in critically ill. Bratisl Lek Listy 2001;102:514

7. Kucer N, Matijatko V, Kis I, Grden D, Brkljacic M, Forsek J, dkk. White blood cell count and neutrophil to lymphocyte ratio in uncomplicated and complicated canine babesiosis caused by Babesia canis canis. Vet Arhiv 2008;78:321-30.

8. De Jager CPC, Wever PC, Gemen EFA, Kusters R, Van Gageldonk-lafeber, Van der Poll T, dkk. The Neutrophillymphocyte count ratio in patients with community acquired pneumonia (CAP). J Plos One 2012;7:1-8

9. Bachrach VR, Schwarz E, Bachrach LR. Breastfeeding and the risk of hospitalization for respiratory disease in infancy: a meta-analysis. Arch Pediatr Adolesc Med 2003; 157:237-43

10. Nataprawira HM, Alwi EH, Adriani N. Faktor risiko morbiditas dan mortalitas pneumonia berat pada anak usia balita. Maj Kedokt Indon 2010;60:443-7

11. Lamberti LM, Grkovic IZ, Walker CLF, Theodoratou E, Nair H, Campbell H,dkk. Breastfeeding for reducing the risk of pneumonia morbidity and mortality in children under two: a systematic literature review and meta analysis. BMC public health 2013;13: 1-18 